\title{
Hepatoprotective Effect of Uncaria rhynchophylla on Thioacetamide-Induced Liver Fibrosis Model
}

\author{
Jeong Won Choi ${ }^{1, *}$, Mi-Rae Shin ${ }^{1, * *}$, Ji Hye Lee ${ }^{2, * *}$ and Seong-Soo Roh ${ }^{1, \dagger, * *}$ \\ ${ }^{I}$ Department of Herbology, College of Korean Medicine, Daegu Haany University, Daegu 42158, Korea \\ ${ }^{2}$ College of Korean Medicine, Semyung University, Jecheon, Chungbuk 27136, Korea
}

Liver fibrosis is a wound-healing response to chronic liver injury, which is caused by the continuous and excess deposition of extracellular matrix (ECM). The aim of this study is to investigate whether Uncaria rhynchophylla water extract (UR) can ameliorate thioacetamide (TAA)-induced liver fibrosis. The liver fibrosis model was induced on C57BL/6 mice by intraperitoneal injection with TAA three times a week for 8 weeks. UR $(200 \mathrm{mg} / \mathrm{kg})$ or silymarin $(50 \mathrm{mg} / \mathrm{kg})$ was administered orally daily for 8 weeks. Biochemical analyses including AST, ALT, MPO, and Ammonia levels were measured in serum. In the mice liver tissues, western blot and histological staining were analyzed. As a result, UR dramatically reduced the levels in serum AST, ALT, MPO, and Ammonia levels. UR treatment regulated NADPH oxidase factors expression, and antioxidant enzymes except for GPx-1/2 were significantly increased via Nrf2 activation Furthermore, pro-inflammatory mediators, such as COX-2 and iNOS were markedly suppressed through the inhibition of NF- $\mathrm{KB}$ activation. Expressions of ECM-related protein including $\alpha$-SMA and Collagen I were noticeably decreased. The additional histological evaluation confirmed that hepatocyte damage and collagenous fiber accumulation were attenuated. Taken together, these data suggest that UR possessed hepatoprotective effects in TAA-induced liver fibrosis via the NF-KB inactivation and Nrf2 activation. Therefore, UR may act as a potential therapeutic drug against liver fibrosis.

Key Words: Uncaria rhynchophylla, Liver fibrosis, Thioacetamide, Oxidative stress, Antioxidant, Anti-inflammatory

서 론

간(Liver)은 신체에서 가장 큰 장기이며 탄수화물, 지방, 단백질 등 영양분의 대사와 약물 대사, 면역 기능, 해독 작용 및 담즙 분비 등 중요한 역할을 수행한다(Park et al., 2018). 현대사회로 들어서면서 수많은 공해물질과 유독물 질에 항상 노출됨에 따라 간은 끓임없이 해독 작용에 시 달리고 있다. 또한, 과도한 정신적 스트레스, 흡연, 과음, 바이러스, 지질 과산화 등은 간에 부담을 증가시켜 이로 인한 만성적인 간질환 환자들을 양산하고 있다(Kim, 2013).
간 섬유화(Liver fibrosis)는 이러한 만성 간손상의 상처치 유 반응이며, 특히 간 성상 세포(hepatic stellate cell, HSC) 의 활성화로 인해 세포외기질(extracellular matrix, $\mathrm{ECM}$ )인 교원질(collagen)의 과잉 축적과 같은 특징을 보이게 된다 (Bataller et al., 2005; Friedman, 2003). 원래 간 섬유화는 가 역적이지만 이 과정이 수십 년에 걸쳐 간경변이나 간암 까지 진행되면 회복하기 힘든 불가역적인 상태에 이르게 된다(Lee and Friedman, 2011). 이처럼 간질환은 신체에 심 각한 영향을 미칠 수 있기 때문에 간을 보호하거나 간기 능을 개선시킬 수 있는 천연소재의 발굴에 집중되고 있다.

Thioacetamide (TAA)는 간독성 물질로 cytochrome p450

Received: August 26, 2021 / Revised: September 13, 2021 / Accepted: September 14, 2021

* Graduate student, ${ }^{* *}$ Professor.

${ }^{\dagger}$ Corresponding author: Seong-Soo Roh. College of Korean Medicine, Daegu Haany University, 136, Sincheondong-ro, Suseong-gu, Daegu 42158, Korea. Tel: +82-53-770-2350, Fax:+82-53-768-6340, e-mail: ddede@dhu.ac.kr

(C) The Korean Society for Biomedical Laboratory Sciences. All rights reserved.

(C) This is an Open Access article distributed under the terms of the Creative Commons Attribution Non-Commercial License (http://creativecommons.org/licenses/by-nc/3.0/) which permits unrestricted non-commercial use, distribution, and reproduction in any medium, provided the original work is properly cited. 
효소에 의해 thioacetamide S-oxide라고 알려진 독성이 강 한 물질로 대사되고, 이로 인해 간에서 간기능 장애, 산 화 스트레스(oxidative stress), 지질 과산화를 유발하는 것 으로 알려져 있다. 특히 TAA에 의해 유발된 산화 스트레 스는 섬유 생성 과정에 관여하여 간세포의 glutathion과 항산화 방어 메커니즘을 감소시키며 지질 과산화 및 자 유 라디칼의 형성을 증가시킨다. 따라서, TAA는 간손상 및 간 섬유화 모델의 유발에 일반적으로 사용되고 있다 (Kim et al., 2000; Marciniak et al., 2018; da Silva et al., 2021).

조구등(Uncaria rhynchophylla)은 꼭두서니과에 속하는 덩굴성 목본식물로 한방에서 가시가 달린 가지를 생약재 로 사용하고 있다. 조구등은 진정 및 진경효능을 가져 각 종 신경성 질환에 널리 처방되고 있으며, 소아고열, 경풍, 자간 등에 효과가 있고 특히 고혈압에 의해 유발된 두통 이나 현기증치료에 효과적인 것으로 알려져 있다(Han et al., 2000; Kim et al., 2002). 조구등의 주요 성분은 alkaloids, flavonoids, terpenes, glycosides, quinovic acid 및 coumarins 등이 보고되고 있으며, 생리활성에 대하여 뇌신경세포와 척수신경세포의 손상에 대한 방어 효과, 비알콜성 지방간 모델에서 인슐린 민감성 개선 효과 및 alkaloid 성분의 혈 압 강화 또는 혈관 확장 효과를 가지고 있다(Heitzman et al., 2005; Kim et al., 2006; Araujo et al., 2018; Loh et al., 2017).

이에 본 연구는 조구등 추출물이 TAA로 유발된 간 섬 유화 모델에서 간 보호 효과와 새로운 기능성 소재로의 활용 가능성을 확인하였으며 그 기전에 대하여 보고하는 바이다.

\section{재료 및 방법}

\section{재료}

시료: 본 실험에서 사용한 조구등은 옹기한약국(Daegu, Korea)에서 구입하여 생약규격집에 맞추어 관능검사를 진 행한 후 약전규격에 적합한 것만을 정선하여 사용하였다. 조구등을 $300 \mathrm{~g}$ 분쇄하여 증류수 $3,000 \mathrm{~mL}$ 첨가한 후 열 탕 추출기를 이용하여 2시간 동안 추출하였다. 얻어진 추 출물은 감압 추출장치로 농축하였으며, 동결 건조기를 이 용해 완전 건조시켜 파우더(수율, $2.2 \%$ )를 얻었다. 파우더 는 $-80^{\circ} \mathrm{C}$ 에서 보관하였고 사용 직전 증류수에 녹여 사용 하였다.

시약: 본 실험에 사용된 gallic acid, folin-ciocalteu's phenol reagent, quercetin, 2-Diphenyl-1-picrylhydrazyl (DPPH), $7 \mathrm{mM}$ 2,2'-azino-bis (3-ethylbenzothiazoline-6-sulphonic acid) (ABTS), thioacetamide (TAA), potassium phosphate monobasic, potassium phosphate dibasic은 Sigma-Aldrich Co. (St. Louis, MO, USA)에서 구입하여 사용하였으며, sodium carbonater과 potassium acetate는 DAEJUNG (Gyeonggi, Korea)에서 구입 하여 사용하였다. L-ascorbic acid, aluminum chloride은 Alfa Aesar (Ward Hill, MA, USA)에서, nitrocellulose membranes는 Amersham GE Healthcare (Little. Chalfont, UK)에서 구입하 였다. Gp91 ${ }^{\text {phox }}$ (Nox2), p22 $2^{\text {phox }}, \mathrm{p} 47^{\text {phox }}$, nuclear factor erythroid2-related factor 2 (Nrf2), kelch-like ECH-associated protein 1 (Keap1), heme oxygenase 1 (HO-1), superoxide dismutase 1 (SOD-1), catalase, glutathione peroxidase-1/2 (GPx-1/2), nuclear

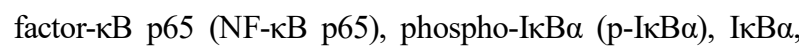
cyclooxygenase-2 (COX-2), NOS2 (iNOS, inducible nitric oxide synthase), $\beta$-actin, histone은 Santa Cruz Biotechnology (Dallas, $\mathrm{TX}, \mathrm{USA}$ )로부터 구입하여 사용하였고, $\alpha$-smooth muscle actin ( $\alpha$-SMA), Collagen I은 Abcam (Cambridge, UK)에서 구입하여 사용하였으며, 2차항체는 GeneTex, Inc. (Irvine, $\mathrm{CA}, \mathrm{USA}$ )에서 구입하여 사용하였다. Protease inhibitor mixture, ethylenediaminetetraacetic acid (EDTA)는 Wako Pure Chemical Industries, Ltd. (Osaka. Japan)에서 구입하여 사용 하였으며, ECL western blotting detection reagents는 GE Healthcare (Arlington Height, IL, USA)로부터 구입하여 사 용하였다. 단백질 정량을 위한 BCA protein assay kit는 Thermo Scientific (Waltham, MA, USA)에서 구입하였다.

실험 동물: 7주령의 웅성 C57BL/6 (Daehan Biolink Co. Ltd., Chungbuk, Korea)를 구입하여 1주일 동안 실험실 환 경에 적응시킨 후 실험을 진행하였으며, 동물 사육실 조 건은 conventional system으로 온도는 $22 \pm 2{ }^{\circ} \mathrm{C}$, 습도는 $50 \pm$ $5 \%$, 명암주기(light: dark cycle)는 12시간 주기로 조절하였 고, 사료(조단백질 $18 \%$ 이상, 조지방 $5.0 \%$ 이상, 조섬유 $5.0 \%$ 이하, 조회분 $8.0 \%$ 이하, 칼슘 $1.0 \%$ 이상, 인 $0.85 \%$ 이상, 칼륨 $0.55 \%$ 이상, 나트륨 $0.25 \%$ 이상, 마그네슘 $0.15 \%$ 이상, NIH-41, Zeigler Bros, Inc., Gardners, PA, USA) 와 물을 충분히 공급하였다. 동물실험의 윤리적, 과학적 타당성 검토 및 효율적인 관리를 위하여 대구한의대학 교 동물실험윤리 위원회(Institutional Animal Care and Use Committee: IACUC)의 승인(승인번호: DHU2021-039)을 받 았다. 


\section{방법}

Total Polyphenol과 Total Flavonoid 측정: Total polyphenol 함량은 Singleton 등의 방법(Singleton and Rossi, 1965)에 따라 측정하였다. $100 \mu \mathrm{L}$ 의 시료에 $10 \%$ FolinCiocalteu's phenol reagent $500 \mu \mathrm{L}$ 와 $7.5 \%$ sodium carbonate $400 \mu \mathrm{L}$ 를 혼합하여 실온의 암소상태에서 30 분 반응시 켰다. 그 후 Microplate reader (Infinite M200 pro, Tecan, Switzerland)를 사용하여 $765 \mathrm{~nm}$ 에서 흡광도를 측정한 뒤, 표준물질인 gallic acid로 표준 검량선을 구하고 total polyphenol 함량(mg gallic acid equivalents (GAE)/g UR)을 산출 하였다.

Total flavonoid의 함량은 Islam 등의 방법(Islam et al., 2015)에 따라 측정하였다. $100 \mu \mathrm{L}$ 의 시료에 Methanol $300 \mu \mathrm{L}, 10 \%$ aluminium chloride solution $20 \mu \mathrm{L}, 1 \mathrm{M}$ potassium acetate solution $20 \mu \mathrm{L}$ 및 증류수 $560 \mu \mathrm{L}$ 를 혼합하여 실온 의 암소상태에서 30 분 반응시켰다. 그 후 Microplate reader 를 사용하여 $415 \mathrm{~nm}$ 에서 흡광도를 측정하여, 표준물질인 quercetin로 표준 검량선을 구하고 total flavonoid 함량 $(\mathrm{mg}$ quercetin equivalent $(\mathrm{QE}) / \mathrm{g} \mathrm{UR})$ 을 산출하였다.

$\mathrm{DPPH}$ 와 $\mathrm{ABTS}$ 라디칼 소거 활성 측정: $\mathrm{DPPH}$ free 라디 칼 소거 활성은 Blois 등의 방법(Blois, 1958)에 따라 측 정하였다. $60 \mu \mathrm{M} \mathrm{DPPH}$ 용액 $100 \mu \mathrm{L}$ 와 농도별로 희석한 시료 용액 $100 \mu \mathrm{L}$ 를 혼합하여 30분간 암소상태로 반응시 킨 후 $540 \mathrm{~nm}$ 에서 흡광도를 측정하였다. 대조군으로는 L-ascorbic acid를 사용하였고, 라디칼을 $50 \%$ 감소시키는 시료의 농도를 $\mathrm{IC}_{50}$ 값으로 나타내었다. $\mathrm{ABTS}$ 라디칼 소 거 활성은 $\operatorname{Re}$ 등의 방법(Re et al., 1999)에 따라 측정하였 다. $7 \mathrm{mM} \mathrm{ABTS}$ 용액과 $2.4 \mathrm{mM}$ potassium persulfate를 혼 합하여 실온의 암소상태에서 약 16 시간 이상 방치하여 $\mathrm{ABTS}^{+}$를 형성시킨 후, 흡광도 $\left(30^{\circ} \mathrm{C}, 415 \mathrm{~nm}\right)$ 값이 $0.70 \pm$ 0.02 가 되도록 ethanol로 희석하였다. 희석한 ABTS 용액 $95 \mu \mathrm{L}$ 와 농도별로 희석한 시료 용액 $5 \mu \mathrm{L}$ 를 혼합하여 15 분간 반응시킨 후 $30^{\circ} \mathrm{C}, 415 \mathrm{~nm}$ 에서 흡광도를 측정하였 다. 대조군으로는 L-ascorbic acid를 사용하였고, 라디칼을 $50 \%$ 감소시키는 시료의 농도를 $\mathrm{IC}_{50}$ 값으로 나타내었다.

DPPH and ABTS radical scavenging activity (\%)

$=\left\{1-\mathrm{OD}_{\text {sample }} / \mathrm{OD}_{\text {blank }}\right\} \times 100$

간 섬유화 모델: 실험군은 정상군(Normal), 대조군(Con- trol), silymarin $50 \mathrm{mg} / \mathrm{kg}$ 투여군(Silymarin), 조구등 추출물 $200 \mathrm{mg} / \mathrm{kg}$ 투여군(UR) 총 4군으로 각각 9마리씩 분류하 였다. 모든 동물은 일정한 시간에 1회/1일 체중을 측정하 였으며, 정상군을 제외한 모든 동물은 8주간 3회/1주 TAA (1주 $100 \mathrm{mg} / \mathrm{kg}, 2$ 3주 $200 \mathrm{mg} / \mathrm{kg}, 4 \sim 8$ 주 $400 \mathrm{mg} / \mathrm{kg}$ ) 복강 투여 및 $\mathrm{DW}$ 에 녹인 해당 약물을 1회/1일 경구투여 하였 다. 실험종료 후 마취하여 심장에서 혈액을 채취하였고 30 분 이내에 $4,000 \mathrm{rpm}, 4^{\circ} \mathrm{C}$ 에서 10 분간 원심분리하여 혈 청을 얻어 $-80^{\circ} \mathrm{C}$ 에서 보관하였으며, 간 조직은 즉시 적출 하여 $-80^{\circ} \mathrm{C}$ 에서 보관하였다(Table 1).

간독성 지표 측정: 혈중 aspartate aminotransferase (AST)와 alanine aminotransferanse (ALT) level은 assay kit (Asanpharm Co., Seoul, Korea)의 프로토콜에 따라 측정하였다.

Ammonia 측정: 혈중 Ammonia 측정은 ammonia assay kit (Abcam, Cambridge, $\mathrm{UK}$ )의 프로토콜에 따라 측정하였다.

산화 스트레스 바이오마커 측정: 혈중 Myeloperoxidase (MPO) 측정은 MPO colorimetric activity assay kit (BioVision, $\mathrm{CA}, \mathrm{USA})$ 의 프로토콜에 따라 측정하였다.

간 조직 western blotting: 간 조직의 세포질을 얻기 위 해 $100 \mathrm{mM}$ Tris- $\mathrm{HCl}$ (pH 7.4), $5 \mathrm{mM}$ Tris- $\mathrm{HCl}$ (pH 7.5), $2 \mathrm{mM}$ $\mathrm{MgCl}, 15 \mathrm{mM} \mathrm{CaCl}, 1.5 \mathrm{M}$ sucrose, $0.1 \mathrm{M}$ DTT, protease inhibitor cocktail을 첨가한 buffer $\mathrm{A}$ 를 넣고 tissue grinder (BioSpec Product, Oklahoma, USA)로 분쇄한 후 아이스 위 에서 30 분간 정치시켰다. 그 후, $10 \% \mathrm{NP}-40$ 용액을 첨가 하여 $12,000 \mathrm{rpm}$ 으로 2 분간 원심분리 하여 세포질을 포 함하고 있는 상층액을 분리하였다. 핵을 얻기 위해 $10 \%$ $\mathrm{NP}-40$ 가 더해진 buffer A에 두 번 헹구고 $100 \mu \mathrm{L}$ 의 buffer C (50 mM HEPES, $0.1 \mathrm{mM}$ EDTA, $50 \mathrm{mM} \mathrm{KCl}, 0.3 \mathrm{mM}$ $\mathrm{NaCl}, 1 \mathrm{mM}$ DTT, $0.1 \mathrm{mM}$ PMSF, $10 \%$ glycerol)를 첨가해 재부유 시킨 뒤 10 분마다 vortex를 3 번 하였다. $4^{\circ} \mathrm{C}$ 에서 $12,000 \mathrm{rpm}$ 으로 10 분간 원심분리한 후 핵을 포함하고 있 는 상층액을 얻어 $-80^{\circ} \mathrm{C}$ 에서 각각 냉동 보관하였다. 간 조 직 세포질에서 $\mathrm{gp} 91^{\text {phox }}, \mathrm{p} 22^{\text {phox }}, \mathrm{p} 47^{\text {phox }}$, Keap1, HO-1, SOD1, catalase, GPx-1/2, p-IкB $\alpha$, IкB $\alpha, \operatorname{COX}-2, \operatorname{NOS} 2, \alpha$-SMA, Collagen I 및 $\beta$-actin과 핵에서 Nrf2, NF-kBp65 및 histone 단백질 발현을 측정하기 위하여 $12 \mu \mathrm{g}$ 의 단백질을 8 $14 \%$ SDS-polyacrylamide gel을 이용하여 전기영동 후, acrylamide gel을 nitrocellulose membrane으로 이동시켰다. 준비 
Table 1. Total polyphenol and total flavonoid contents of UR

\begin{tabular}{ccc}
\hline \hline & $\begin{array}{l}\text { Total polyphenol } \\
(\mathrm{mg} \mathrm{GAE} / \mathrm{g} \text { UR })\end{array}$ & $\begin{array}{c}\text { Total flavonoid } \\
(\mathrm{mg} \mathrm{QE} / \mathrm{g} \mathrm{UR})\end{array}$ \\
\hline UR & $82.96 \pm 0.13$ & $23.28 \pm 0.63$ \\
\hline
\end{tabular}

All experiments were performed in triplicate and expressed mean \pm SEM

된 membrane에 각각의 1 차 antibody $(1: 1,000)$ 를 처리하여 $4^{\circ} \mathrm{C}$ 에서 overnight 시킨 다음 PBS-T로 6 분마다 5 회 세척 하고, 각각 처리된 1차 antibody에 사용되는 2차 antibody $(1: 3,000)$ 를 사용하여 상온에서 1 시간 30 분 반응시킨 후, PBS-T로 6분마다 5회 세척하였다. 그 후 enhanced chemiluminescence (ECL) 용액에 노출시켜 Sensi-Q2000 Chemidoc (Lugen Sci Co. Ltd, Seoul, Korea)를 이용해 단백질 발현을 확인하였으며, 해당 band를 ATTO Densitograph Software (ATTO Corporation, Tokyo, Japan) 프로그램을 사용 하여 정량하였다. 각각의 단백질 수준을 Normal군의 단백 질 수준으로 나눈 후 상대적 비로 나타내었다(represented as 1).

조직학적 관찰: 간 조직을 $10 \%$ neutral buffered formalin 에 고정시킨 후 graded alcohol로 탈수시키고, 파라핀으 로 포매하여 표본을 제작한 후 microtome으로 $5 \mu \mathrm{m}$ 두 께의 조직 절편을 제작하여 hematoxylin \& eosin (H\&E)으 로 염색하였으며, xylene clearing을 거쳐 permount로 처리 하여 고정하였다. Masson's trichrome (MT) 염색을 위해 weigert iron hematoxylin에서 7분간 염색하였으며, 세척 후 iebrich scarlet-acid fuchsin에서 2분 동안 염색하였다. 그 후, phosphotungstic-phosphomolybdic acid에서 7분 동안 배양 하고, aniline blue로 10 분 동안 염색하였으며, $1 \%$ 아세트 산에서 3 분 동안 고정하여 광학현미경(DSCHX50V; Sony, Tokyo, Japan)을 이용하여 조직의 특이 병변 유무를 관찰 하였다.

통계분석: In vitro의 수치는 mean $\pm \mathrm{SEM}$ 으로 표시하였 고 Invivo의 수치는 mean $\pm \mathrm{SD}$ 로 표시하였으며, $\mathrm{SPSS}$ program for windows version 25 (SPSS Inc., Chicago, USA)를 사용하여 one-way analysis of variance (ANOVA) test를 실 시한 후 least-significant differences (LSD) test로 사후검증 을 실시하여 각 군의 평균 차이에 대한 통계적 유의성을 $P<0.05$ 에서 검증하였다.
Table 2. DPPH and ABTS radical scavenging activity of UR

\begin{tabular}{ccc}
\hline \hline & DPPH & ABTS \\
\hline UR & $9.12 \pm 0.58$ & $21.34 \pm 1.19$ \\
\hline
\end{tabular}

All experiments were performed in triplicate and expressed mean \pm SEM

결 과

\section{Total Polyphenol와 Total Flavonoid 함량 측정}

$\mathrm{UR}$ 의 total polyphenol와 total flavonoid 함량 측정 결과, total polyphenol 함량은 $82.96 \pm 0.13 \mathrm{mg} \mathrm{GAE} / \mathrm{g}$ UR, total flavonoid 함량은 $23.28 \pm 0.63 \mathrm{mg} \mathrm{QE} / \mathrm{g}$ UR으로 나타났다 (Table 1).

\section{$\mathrm{DPPH}$ 와 $\mathrm{ABTS}$ 라디칼 소거 활성}

$\mathrm{DPPH}$ free 라디칼 소거 활성을 측정한 결과, 양성대조 물질로 사용한 $\mathrm{L}$-ascorbic acid의 $\mathrm{IC}_{50}$ 값은 $1.23 \pm 0.05 \mu \mathrm{g}$ $\mathrm{mL}$ 로 나타났고, $\mathrm{UR}$ 의 $\mathrm{IC}_{50}$ 값은 $9.12 \pm 0.27 \mu \mathrm{g} / \mathrm{mL}$ 로 나 타났다. ABTS free 라디칼 소거 활성을 측정한 결과, 양 성 대조물질로 사용한 L-ascorbic acid의 $\mathrm{IC}_{50}$ 값은 $3.56 \pm$ $0.06 \mu \mathrm{g} / \mathrm{mL}$ 로 나타났고, $\mathrm{UR}$ 의 $\mathrm{IC}_{50}$ 값은 $21.34 \pm 0.46 \mu \mathrm{g} / \mathrm{mL}$ 로 나타났다(Table 2).

\section{혈중 AST 및 $\mathrm{ALT}$ 측정}

분리한 혈청의 AST 측정 결과 Normal군 대비 Control 군 $(P<0.001)$ 에서 7 배 이상 크게 증가하였고, Control군 대 비 $\mathrm{UR}$ 군 $(P<0.001)$ 에서 $44 \%$ 유의적인 감소가 나타났다.

ALT 측정 결과 Normal군 대비 Control군 $(P<0.001)$ 에서 3 배 이상의 높은 증가를 보였으며, Control군 대비 UR군 $(P<0.001)$ 에서 $47 \%$ 유의적으로 감소하였고 Silymarin군 과 비교하였을 때도 $16 \%$ 낮은 수치로 보여진다(Fig. 1).

\section{혈중 Ammonia와 MPO 측정}

분리한 혈청의 Ammonia 농도 측정 결과, Normal군 대 비 Control군 $(P<0.001)$ 에서 약 3 배의 유의적인 증가가 나 타났고, $\mathrm{UR}$ 군 $(P<0.001)$ 에서 $18 \%$ 유의적으로 감소하였다.

$\mathrm{MPO}$ 측정 결과 Normal군 대비 Control군 $(P<0.001)$ 에서 약 5 배의 높은 증가가 나타났고, Control군 대비 UR군 $(P<0.001)$ 에서 $47 \%$ 유의적으로 감소하여 Silymarin군과 유사한 수치까지 감소하였다(Fig. 2). 

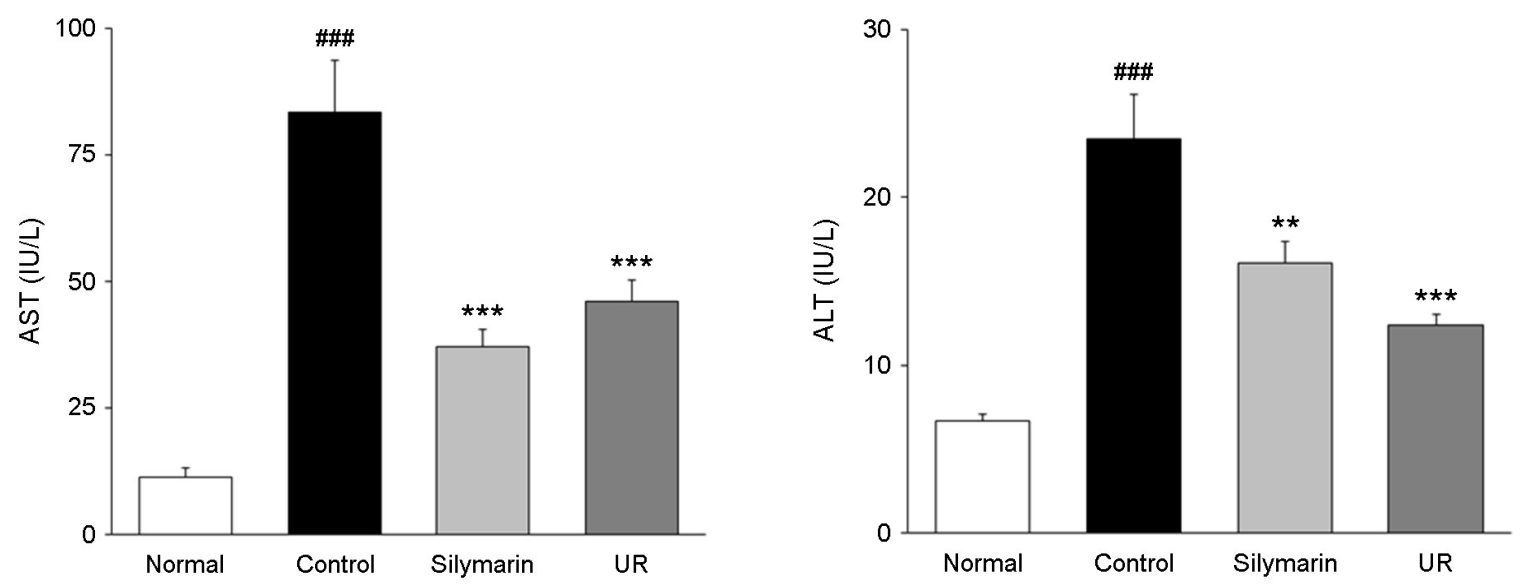

Fig. 1. AST and ALT levels in serum. Normal, normal mice; Control, liver fibrosis-induced with distilled water mice; Silymarin, liver fibrosis-induced with silymarin $50 \mathrm{mg} / \mathrm{kg}$ mice; UR, liver fibrosis-induced with UR $200 \mathrm{mg} / \mathrm{kg}$ mice. All data are expressed as mean \pm SD $(\mathrm{n}=9)$. Significance: ${ }^{\# \#} P<0.001$ versus normal mice, ${ }^{* *} P<0.01,{ }^{* * *} P<0.001$ versus liver fibrosis-induced mice.
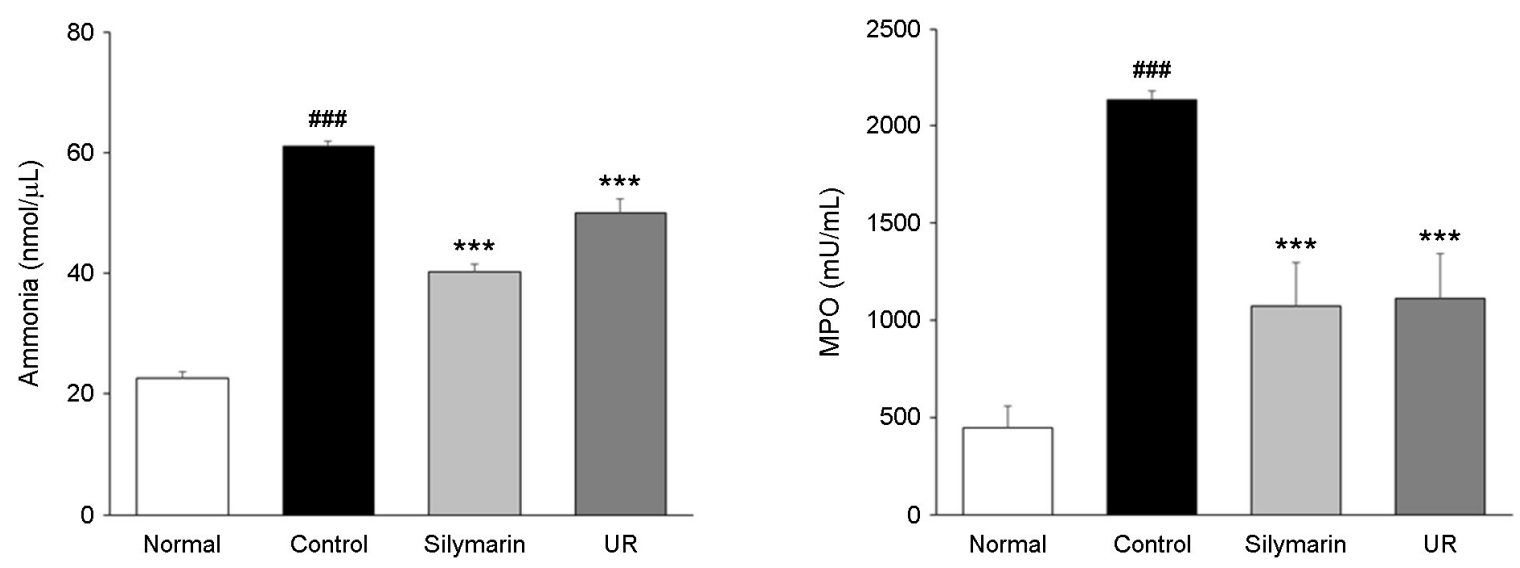

Fig. 2. Ammonia and MPO levels in serum. Normal, normal mice; Control, liver fibrosis-induced with distilled water mice; Silymarin, liver fibrosis-induced with silymarin $50 \mathrm{mg} / \mathrm{kg}$ mice; UR, liver fibrosis-induced with UR $200 \mathrm{mg} / \mathrm{kg}$ mice. All data are expressed as mean $\pm \mathrm{SD}(\mathrm{n}=9)$. Significance: ${ }^{\ldots \prime \prime} P<0.001$ versus normal mice, ${ }^{* * *} P<0.001$ versus liver fibrosis-induced mice.

\section{간 조직 western blotting}

NADPH oxidase 발현량 분석: NADPH oxidase인 gp91 ${ }^{\text {phox }}$, $\mathrm{p} 22^{\mathrm{phox}}$ 및 $\mathrm{p} 47^{\mathrm{phox}}$ 의 발현량을 분석한 결과, $\mathrm{gp} 91^{\mathrm{phox}}$ 의 경 우 Normal군 대비 Control군에서 $50 \%$ 유의하게 증가하였 고 Control군 대비 Silymarin군에서는 유의적인 변화가 나 타나지 않았지만 UR군에서는 $21 \%$ 유의적으로 감소하였 다. p2 $2^{\mathrm{phox}}$ 와 $\mathrm{p} 47^{\mathrm{phox}}$ 의 경우 Normal군 대비 Control군에서 $30 \%, 20 \%$ 증가하였고, $\mathrm{UR}$ 군에서는 $29 \%, 21 \%$ 유의하게 감소하였다(Fig. 3).

항산화 단백질 Nrf2와 Keap1 발현량 분석: 항산화 단백
질 Nrf2와 Keap1의 발현량을 분석한 결과, Nrf2는 Normal 군에 비하여 Control군에서 $46 \%$ 감소하였고, Control군에 비하여 UR군에서 2 배 이상 유의하게 증가하여 Normal군 과 유사한 수치를 나타냈다. Keap1의 경우, Normal군에 비 하여 Control군에서 $10 \%$ 가량 유의하게 증가하였고, UR군 에서 $22 \%$ 유의적으로 감소하였다(Fig. 4).

항산화 효소 발현량 분석: 항산화 효소 HO-1, SOD-1, catalase 및 $\mathrm{GPx}-1 / 2$ 의 발현량을 분석한 결과, Normal군 대 비 Control군에서 각각 $52 \%, 50 \%, 15 \%, 34 \%$ 유의하게 감 소하였으며, Control군 대비 UR군에서 각각 $50 \%, 42 \%$, $32 \%$ 유의적으로 증가하였으나, $\mathrm{GPx}-1 / 2$ 는 $17 \%$ 증가하는 

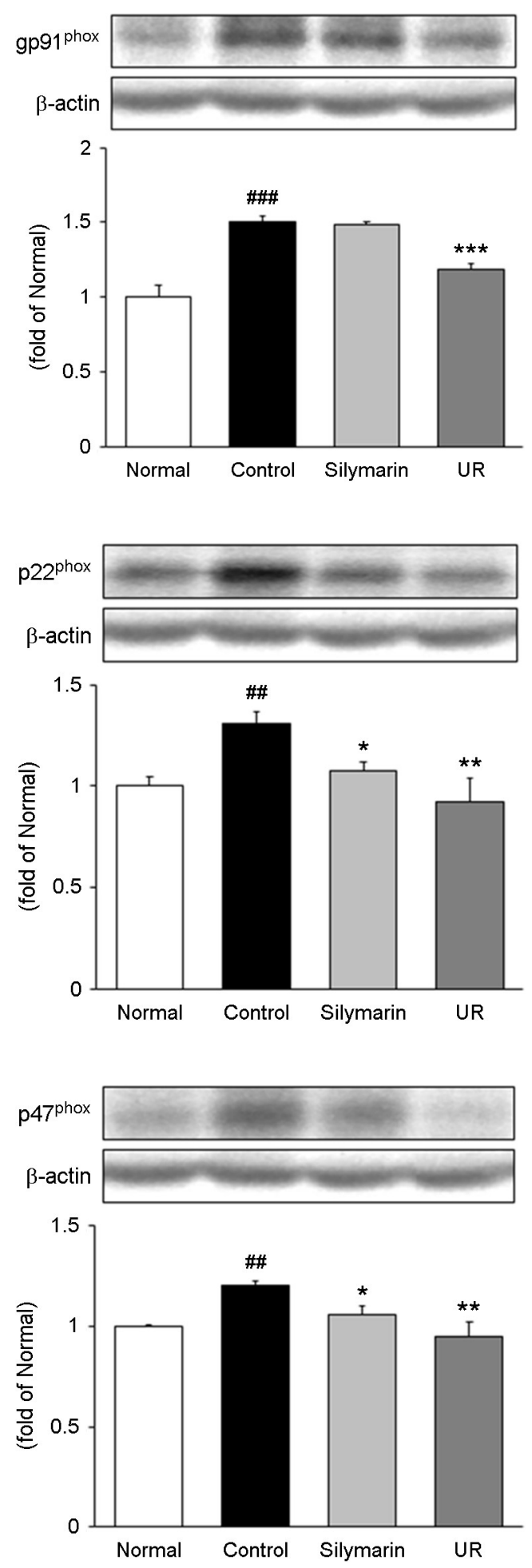

Fig. 3. Expression of NADPH oxidase. Normal, normal mice; Control, liver fibrosis-induced with distilled water mice; Silymarin, liver fibrosis-induced with silymarin $50 \mathrm{mg} / \mathrm{kg}$ mice; UR, liver fibrosis-induced with UR $200 \mathrm{mg} / \mathrm{kg}$ mice. All data are expressed as mean $\pm \mathrm{SD}(\mathrm{n}=9)$. Significance: ${ }^{\#} P<0.01,{ }^{\# \# \#} P<0.001$ versus normal mice, ${ }^{*} P<0.05,{ }^{* *} P<0.01,{ }^{* * *} P<0.001$ versus liver fibrosisinduced mice.
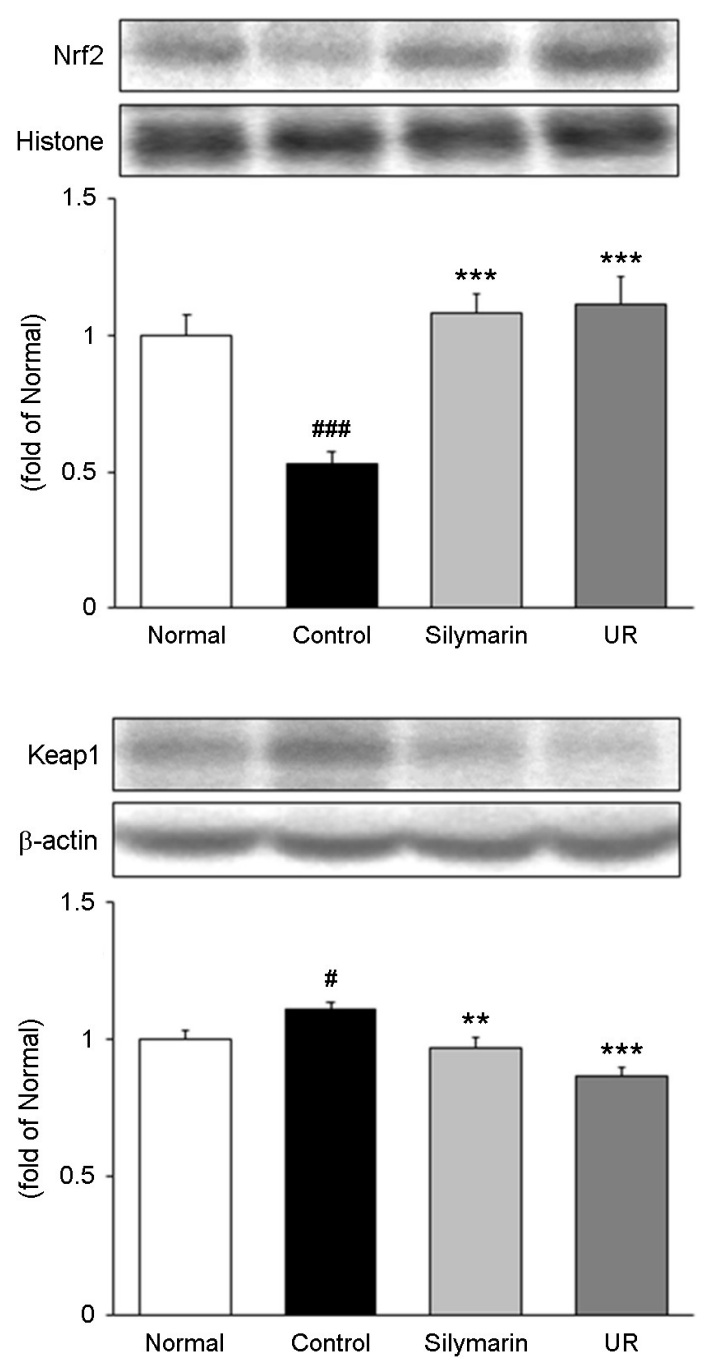

Fig. 4. Expression of Nrf2 and Keap1. Normal, normal mice; Control, liver fibrosis-induced with distilled water mice; Silymarin, liver fibrosis-induced with silymarin $50 \mathrm{mg} / \mathrm{kg}$ mice; UR, liver fibrosis-induced with UR $200 \mathrm{mg} / \mathrm{kg}$ mice. All data are expressed as mean $\pm \mathrm{SD}(\mathrm{n}=9)$. Significance: ${ }^{\sharp} P<0.05,{ }^{\# \#} P<0.001$ versus normal mice, ${ }^{* *} P<0.01,{ }^{* * *} P<0.001$ versus liver fibrosis-induced mice.

경향을 보여주었다. 특히 catalase의 발현은 Silymarin군과 비교하였을 때 약 $23 \%$ 높은 유의성을 보였다(Fig. 5).

염증관련 단백질 발현량 분석: 염증관련 단백질 $\mathrm{p}-\mathrm{I \kappa B} \alpha$, $\mathrm{NF}-\kappa B p 65, \mathrm{COX}-2$ 및 iNOS (NOS2)의 발현량을 분석한 결과, Normal군 대비 Control군에서 각각 $25 \%, 55 \%, 42 \%$, $40 \%$ 유의하게 증가하였고, Control군 대비 UR군에서 $37 \%$, $25 \%, 45 \%, 20 \%$ 유의하게 감소하였다. 특히 $\mathrm{p}-\mathrm{I} \kappa \mathrm{B} \alpha, \mathrm{NF}-$ kBp65 및 COX-2의 발현은 Silymarin군과 비교하였을 때 약 $11 \%, 6 \%, 11 \%$ 높은 유의성을 보였다(Fig. 6). 

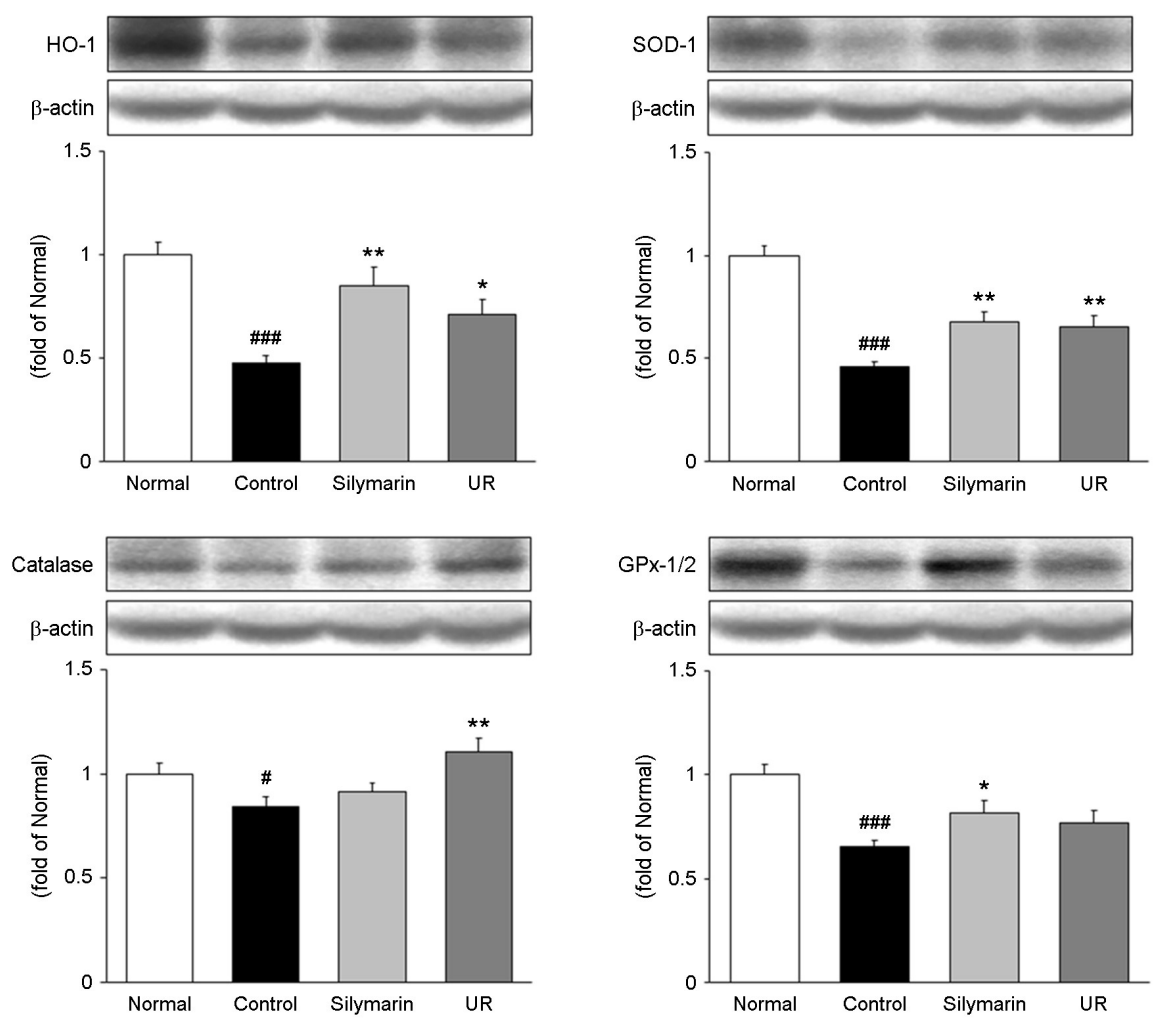

Fig. 5. Expression of antioxidant enzymes. Normal, normal mice; Control, liver fibrosis-induced with distilled water mice; Silymarin, liver fibrosisinduced with silymarin $50 \mathrm{mg} / \mathrm{kg}$ mice; UR, liver fibrosis-induced with UR $200 \mathrm{mg} / \mathrm{kg}$ mice. All data are expressed as mean $\pm \mathrm{SD}(\mathrm{n}=9)$. Significance: ${ }^{\sharp} P$ $<0.05,{ }^{\# \#} P<0.001$ versus normal mice, ${ }^{*} P<0.05,{ }^{* *} P<0.01$ versus liver fibrosisinduced mice.
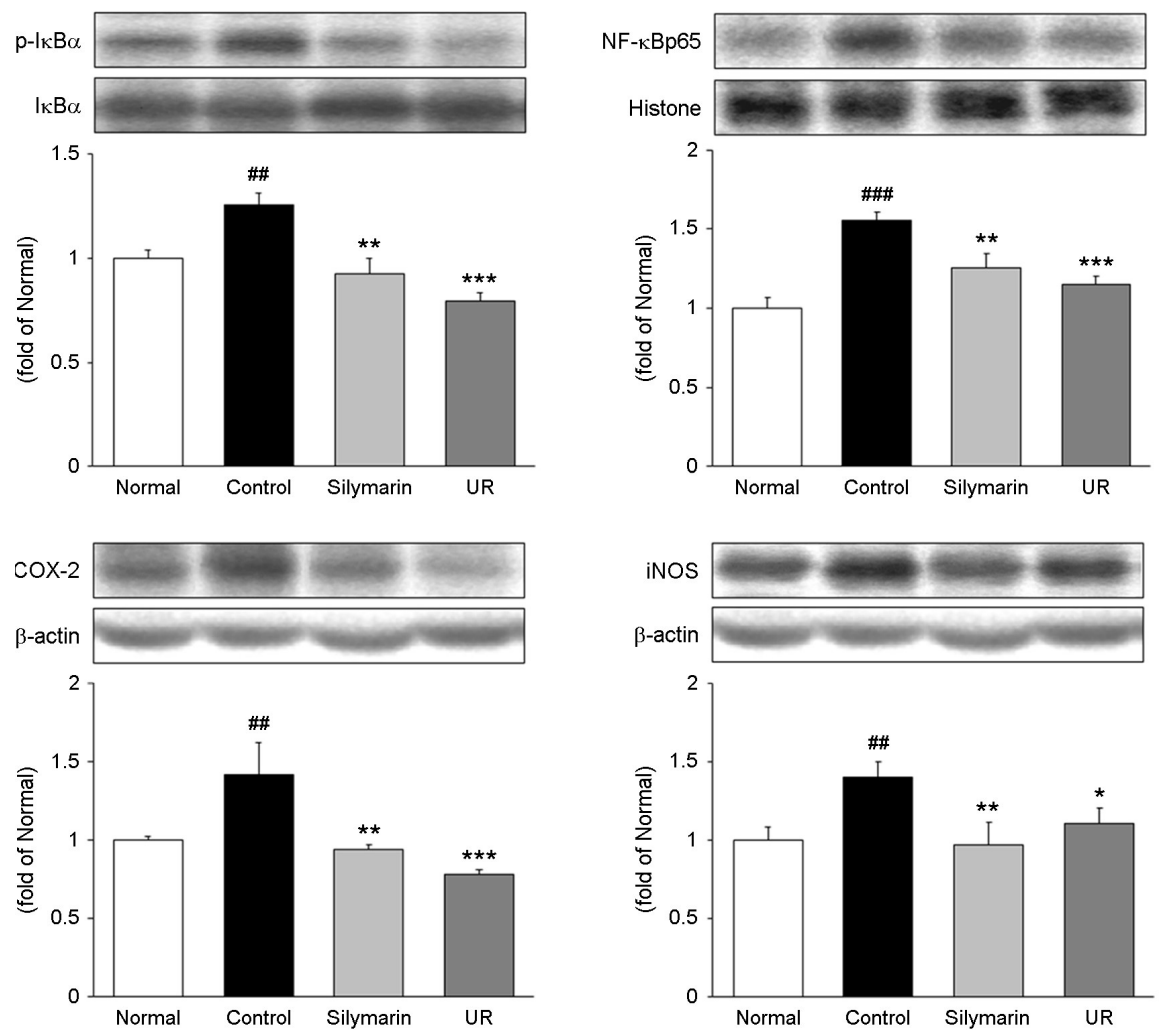

Fig. 6. Expression of inflammatoryrelated protein and inflammatory mediators. Normal, normal mice; Control, liver fibrosis-induced with distilled water mice; Silymarin, liver fibrosisinduced with silymarin $50 \mathrm{mg} / \mathrm{kg}$ mice; UR, liver fibrosis-induced with UR $200 \mathrm{mg} / \mathrm{kg}$ mice. All data are expressed as mean $\pm \mathrm{SD}(\mathrm{n}=9)$. Significance: ${ }^{\#} P$ $<0.01,{ }^{\# \#} P<0.001$ versus normal mice, ${ }^{*} P<0.05,{ }^{* *} P<0.01,{ }^{* * *} P<0.001$ versus liver fibrosis-induced mice. 

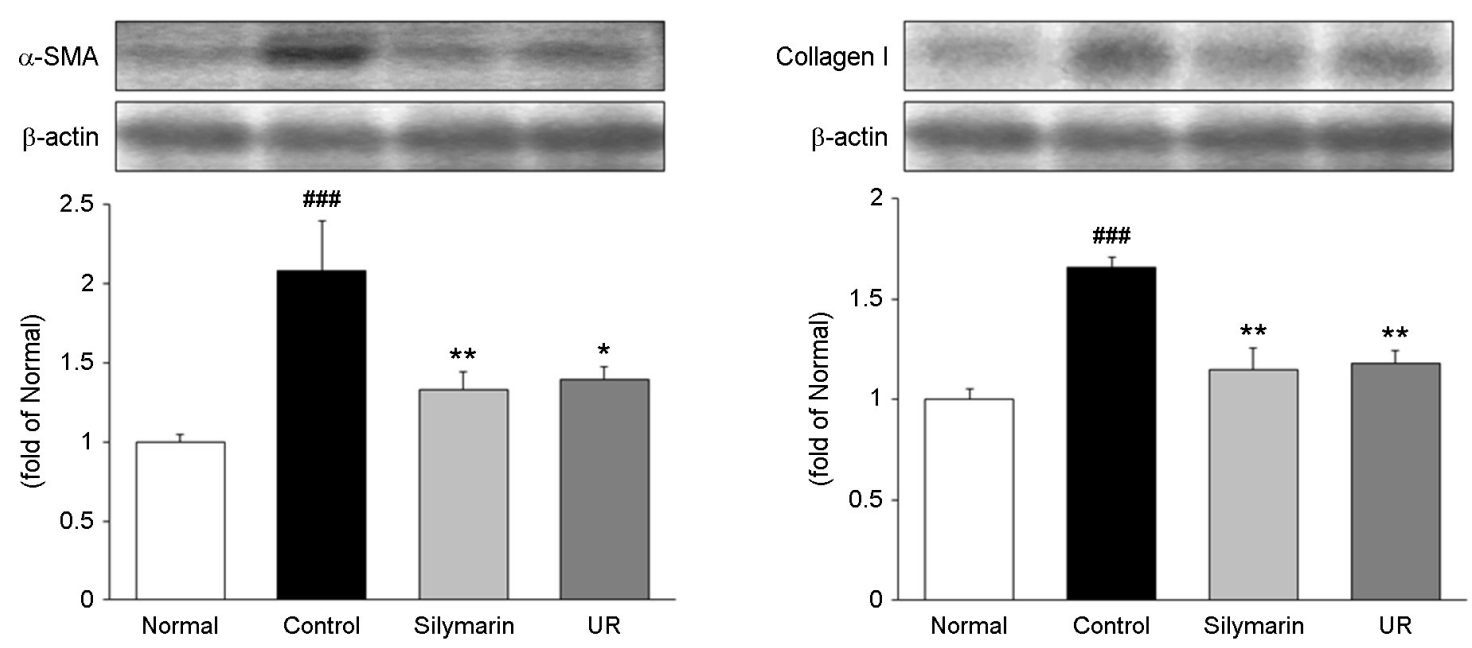

Fig. 7. Expression of extracellular matrix (ECM)-related proteins. Normal, normal mice; Control, liver fibrosis-induced with distilled water mice; Silymarin, liver fibrosis-induced with silymarin $50 \mathrm{mg} / \mathrm{kg}$ mice; UR, liver fibrosis-induced with UR $200 \mathrm{mg} / \mathrm{kg}$ mice. All data are expressed as mean $\pm \mathrm{SD}(\mathrm{n}=9)$. Significance: ${ }^{\#} P<0.001$ versus normal mice, ${ }^{*} P<0.05,{ }^{* *} P<0.01$ versus liver fibrosis-induced mice.

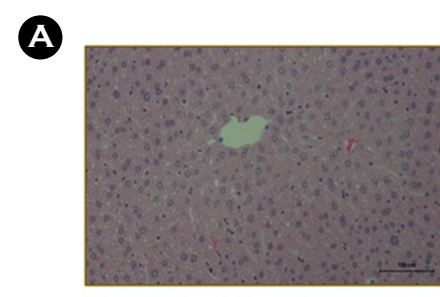

Normal

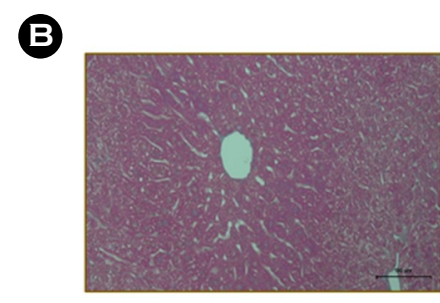

Normal

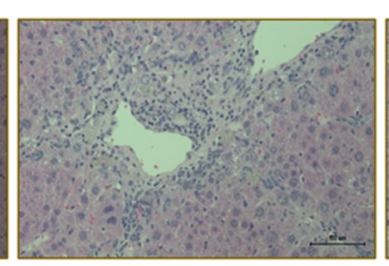

Control

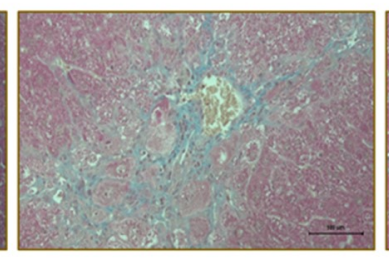

Control

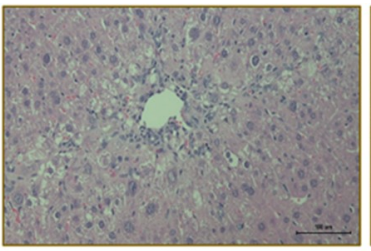

Silymarin

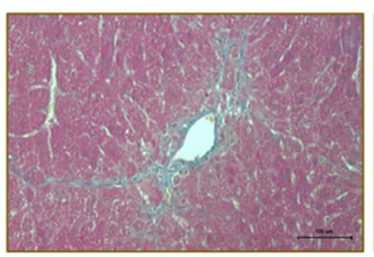

Silymarin

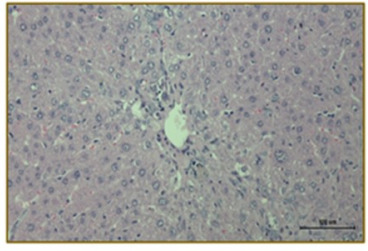

UR

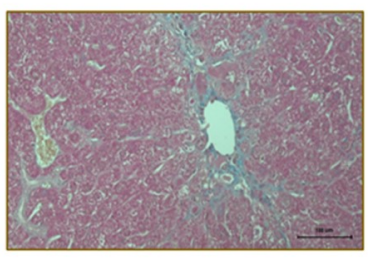

UR

Fig. 8. Histological analysis. Liver histological analysis through hematoxylin and eosin (H\&E); (A) and Masson's trichrome (MT); (B) staining (Original magnification $\times 200$ ). Normal, normal mice; Control, liver fibrosis-induced with distilled water mice; Silymarin, liver fibrosis-induced with silymarin $50 \mathrm{mg} / \mathrm{kg}$ mice; UR, liver fibrosis-induced with UR $200 \mathrm{mg} / \mathrm{kg}$ mice.

세포외기질 관련 단백질 발현량 분석: 섬유화 인자 $\alpha-$ $\mathrm{SMA}$ 와 Collagen I의 발현량을 분석한 결과, $\alpha-\mathrm{SMA}$ 는 Normal군에 비하여 Control군에서 2배 증가하였고, Control 군에 비하여 UR군에서 $32 \%$ 유의하게 감소하였다. Collagen I의 경우, Normal군에 비하여 Control군에서 $66 \%$ 가 량 유의하게 증가하였고, UR군에서 $29 \%$ 유의적으로 감 소하였다(Fig. 7).

조직병리학적 분석: 간 조직을 $\mathrm{H \& E}$ 염색으로 관찰한 결
과, Normal군에 비하여 Control군에서는 TAA에 의한 간 세포의 비대, 괴사 및 염증세포 침윤의 증가를 관찰할 수 있었다. Control군에 비해 UR군에서 세포 변화 정도가 감 소하여 섬유화 정도가 확연히 개선된 것이 나타났다. MT 염색 결과 Normal군에 비하여 Control군에서는 넓은 범위 의 교원섬유의 침착을 확인하였으며, UR군에서는 Control 군에 비하여 교원섬유의 침착 및 조직학적 섬유화 변화 가 완화되었음을 확인하였다(Fig. 8). 


\section{고 찰}

간은 체내 영양소 대사, 혈액 조절, 면역체계, 지질 및 콜레스테롤 항상성 조절 등의 생리적 과정에서 중요한 역할을 수행한다(Trefts et al., 2017). 하지만 현대인들은 음 주, 흡연, 과도한 스트레스 및 약물 등의 위험요소에 항 상 노출되어 있으며, 이로 인해 인체의 대사 기능을 수행 하는 간세포가 지속적으로 손상을 받게 된다. 간 손상의 지속은 간 섬유증, 간경변 및 간세포 암종 같은 다른 간 질환으로 악화되어질 수 있다(Park et al., 2015; Han et al., 2019). 이 중 간 섬유화는 만성적인 간 손상에 대한 간의 상처치유 반응으로서 세포외기질(extracellular matrix, ECM) 의 새로운 침착과 흡수 사이에 생긴 불균형의 결과로 발 생된다(Lackner and Tiniakos, 2019). Thioacetamide (TAA)는 간독성 물질로 1948년부터 사용되어 왔으며, TAA는 생물 에서 S-oxide (TASO)로 산화된 후 S,S-dioxide $\left(\mathrm{TASO}_{2}\right)$ 로 대사되어 만성적으로 사용될 때 간 섬유화를 유발하는 것 으로 잘 알려져 있다(Hajovsky et al., 2012). 이에 본 연구에 서는 TAA로 유도한 간 섬유화 동물 모델에서 조구등 추 출물을 경구투여 하였을 때 간 보호 효과와 그 기전을 규명하기 위해 혈액 내 간 손상 지표의 변화, 염증관련 인자, 항산화 인자, 섬유화 인자 및 조직병리학적 변화를 관찰하였다.

간 섬유화 유발을 위해 8 주간 $\mathrm{TAA}$ 를 3회/1주(1주 $100 \mathrm{mg} / \mathrm{kg}, 2 \sim 3$ 주 $200 \mathrm{mg} / \mathrm{kg}, 4 \sim 8$ 주 $400 \mathrm{mg} / \mathrm{kg}$ )로 복강 투여 하였고, DW에 녹인 조구등 추출물을 $200 \mathrm{mg} / \mathrm{kg}$ 로 1 회/1일 경구투여 한 뒤 부검 후 얻은 혈청과 간조직을 분석하였다.

Aspartate aminotransferase (AST)와 alanine aminotransferase (ALT)는 간세포에서 amino acids와 ketoacids 사이의 amino 전달을 촉매하는 효소이다. 간세포가 손상되면 세포막의 투과성이 증가하고, 간세포의 AST와 ALT가 혈액으로 방 출되어 혈청 내 수치가 높아지게 된다. 비정상적으로 증 가하면 간세포의 손상과 괴사를 유발하기 때문에 $\mathrm{AST}$ 와 $\mathrm{ALT}$ 는 간기능 평가의 중요 항목으로 여겨지고 있다 $\mathrm{Xu}$ et al., 2018). 혈중 AST와 ALT를 분석한 결과, Control군 에 비해 UR군에서 유의적인 감소가 나타났다.

Ammonia는 주로 장내 세균과 효소에 의해 장에서 생 성되고 주로 간에서 해독되지만, 만성적인 간 손상이 이 루어지면 간세포 기능 장애로 인해 혈중에 Ammonia가 축적된다(Ninan and Feldman, 2017; Nam et al., 2019). 혈중
Ammonia 수치를 확인한 결과 Control군에 비해 UR군에 서 유의하게 감소하는 양상을 보였다.

Myeloperoxidase (MPO)는 호중구에 의해 생성되는 염 증성 효소로, 염증상태의 조직에서 지질 과산화의 주요 한 원인으로 여겨지고 있으며, 침윤된 호중구는 cytokine, chemokine 및 reactive oxygen species (ROS)와 같은 염증 매개체를 방출하고 이로 인해 간세포의 손상을 유래할 수 있다. $\mathrm{MPO}$ 의 억제는 간질환의 진행 및 간 섬유증을 약화 시킨다고 알려져 있다(Liu et al., 2018; Piek et al., 2019; Koop et al., 2020). 혈청 $\mathrm{MPO}$ 를 측정한 결과, Control군 대비 UR 군에서 $\mathrm{MPO}$ 를 효율적으로 억제하는 것으로 나타났다.

이러한 결과는 조구등 추출물이 혈청 내 AST와 ALT 수치의 감소로 보아 간기능을 개선하고 세포손상을 억제 시켰으며, 간세포에 유해한 ammonia와 $\mathrm{MPO}$ 의 축적을 저 해시켜 간 섬유화에 대한 보호 효과를 나타낸 것으로 보 여진다.

간조직에서 단백질 발현을 평가하기 위해 western blotting을 수행하였다. ROS는 반응성 분자를 포함하는 산 소 라디칼로 정상적인 산소 대사에서는 세포성장과 신 호전달을 조절하여 세포 항상성을 유지하는데 중요한 역 할을 한다. 하지만 NADPH oxidase에 의해 ROS가 대량생 산되고 세포에 축적되면 조직손상 및 기관 기능 장애를 초래한다. Gp91-phox는 NADPH oxidase의 필수적 요소로 $\mathrm{p} 22^{\mathrm{phox}}$ 와 결합한 세포막 단백질로 존재하며 과도하게 횔 성화될 때 생성된 ROS의 생성을 촉진하여 간 섬유증의 발달을 유도할 수 있다(Liang et al., 2016; Gan et al., 2018) 또한 세포질 단백질에 속하는 $\mathrm{p} 47^{\mathrm{phox}}$ 는 활성화에 직접적 으로 관여하지는 않지만 oxidase의 활성화를 촉진하는 효 소로 작용하며, 대표적인 $\mathrm{ROS}$ 인 $\mathrm{O}_{2}^{-}$생성과 연관된 것으 로 알려져 있다(Brandes et al., 2002). 따라서 NADPH oxidase의 발현을 억제하는 물질은 간 섬유화의 유망한 치료 제로 간주되고 있다. 간조직에서 단백질 발현 확인 결과 NOX2는 Control군 대비 Silymarin군에서 변화가 나타나지 않았지만 Control군 대비 UR군에서 유의하게 감소하였으 며, $\mathrm{p} 22^{\mathrm{phox}}$ 와 $\mathrm{p} 47^{\mathrm{phox}}$ 또한 유의하게 감소하였다.

산화 스트레스에 대한 세포방어 시스템의 주요한 조절 은 Nrf2에 의해 나타난다. Nuclear factor-erythroid 2-related factor 2 (Nrf2)는 정상 상태에서 Nrf2를 억제하는 역할 을 하는 kelch-like ECH-associated protein 1 (Keap1)과 결합 된 상태로 존재한다. 하지만 산화 스트레스를 받게 되면 Keap1의 변형에 의해 결합이 풀어지게 되고 $\mathrm{Nrf2}$ 가 핵 내로 이동하여 ARE sequence에 결합하면서 항산화 효소 
의 발현을 촉진시킨다(Li et al., 2017). Nrf2의 핵 내 발현 을 확인한 결과, Control군에 비해 UR군에서 2배 이상 유 의하게 증가하였고, 세포질 내 Keap1의 발현을 확인한 결 과, Control군에 비해 UR군에서 유의하게 감소하였다.

산화 스트레스가 발생하면 ROS가 방어체계를 공격하 여 항산화 효소가 손실된다(Jia et al., 2014). 산화 스트레 스에 대해 방어하는 항산화 효소 중 heme oxygenase 1 (HO-1)은 혈색소 구성요소인 heme을 분해하여 항산화제 인 일산화탄소와 bilirubin을 생성하여 항산화 작용을 한 다(Bataille and Manautou, 2012). 또한 superoxide dismutase 1 (SOD-1), catalase 및 glutathione peroxidase-1/2 (GPx-1/2) 는 산화 스트레스로부터 세포를 보호하고 간세포의 괴사 를 억제함으로써 항산화 작용을 하는 것으로 알려져 있 다(Wu et al., 2019). 항산화 효소의 발현량을 확인한 결과, Control군 대비 UR군에서 HO-1, SOD-1 및 catalase의 유의 적인 증가가 나타났고, 반면 $\mathrm{GPx}-1 / 2$ 은 약 $17 \%$ 증가하는 경향을 보였다.

만성적인 간질환에서 염증은 섬유화와 관련된 중요한

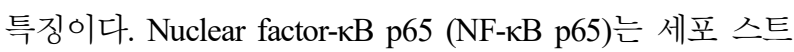
레스에 반응하여 전사 조절의 중심적인 역할을 하며 간 염, 간경변증 및 간세포 암종을 포함하여 간에 영향을 미 치는 다양한 병증과 간 항상성 유지에서 중요한 매개체 로 작용한다. NF- $\mathrm{kB}$ p65는 자극에 의해 활성화될 때 결합 되어 있던 $\mathrm{I} \kappa \mathrm{B} \alpha$ 의 인산화와 분해로 인해 핵 내로 이동하 여 결과적으로 cyclooxygenase-2 (COX-2), iNOS (inducible nitric oxide synthase)와 같은 염증성 매개인자의 분비를 촉진한다고 알려져 있다(Robinson and Mann, 2010; Han et

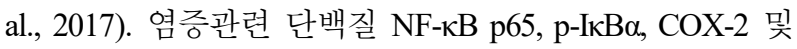
$\mathrm{iNOS}$ 의 발현을 확인한 결과 모든 인자가 Control군 대비 $\mathrm{UR}$ 군에서 유의하게 감소한 것을 확인하였다.

간 섬유화는 근본적으로 $\mathrm{ECM}$ 의 축적에 의해 유도되 는데 $\mathrm{ECM}$ 의 생성에 주요한 역할을 하는 것이 간 성상 세포이다. 활성화 된 간 성상 세포는 섬유화를 촉진시키 는 cytokine을 방출하고 결과적으로 $\mathrm{ECM}$ 의 구성요소인 Collagen I의 축적을 유도하고 이와 직접적인 연관을 가 지는 $\alpha$-smooth muscle actin ( $\alpha$-SMA)의 발현을 증가시킨다 (Carpino et al., 2005; Yoon et al., 2020). $\alpha$-SMA와 Collagen I 발현량을 분석한 결과, Control군에 비하여 UR군에서 유 의하게 감소하였다. 또한, 조직병리학적 분석에서 조구등 추출물은 $\mathrm{TAA}$ 에 의한 조직 내 염증성 병변, 염증세포 침 윤 및 교원섬유의 침착을 현저하게 경감시킨 것이 확인 되었다.
본 연구에서는 $\mathrm{TAA}$ 로 간 섬유화를 유도한 $\mathrm{C} 57 \mathrm{BL} / 6$ mice 모델에서 조구등 추출물은 산화 스트레스를 조절하 고, Nrf2-Keap1 경로를 활성화시켜 항산화 효소의 발현을 증가시켰다. 또한, 염증반응의 조절에 중추적인 역할을 하 는 NF- $\mathrm{KB}$ p65의 핵 내 이동을 조절하여 염증성 매개인자 의 발현을 억제하였고, $\mathrm{ECM}$ 의 축적과 연관된 인자인 $\alpha$ $\mathrm{SMA}$ 와 Collagen I의 발현을 경감시켰다. 조직병리학적 변 화를 분석하였을 시 $\mathrm{TAA}$ 에 의한 손상을 현저하게 완화 시켰다. 따라서, 조구등 추출물이 간기능 보호와 간 섬유 화 개선에 효과적으로 이용할 수 있는 잠재적 천연소재 임을 제시하는 바이다.

\section{ACKNOWLEDGEMENT}

This work was supported by the National Research Foundation of Korea (NRF) grant funded by the Korea government (MSIT) (No.2018R1A5A2025272).

\section{CONFLICT OF INTEREST}

The authors declare that they have no conflict of interest.

\section{REFERENCES}

Araujo LCC, Feitosa KB, Murata GM, et al. Uncaria tomentosa improves insulin sensitivity and inflammation in experimental NAFLD. Sci Rep. 2018. 8: 11013.

Bataille AM, Manautou JE. Nrf2: a potential target for new therapeutics in liver disease. Clin Pharmacol Ther. 2012. 92: 340 348.

Bataller R, Brenner DA. Liver fibrosis. J Clin Invest. 2005. 115 209-218.

Blois MS. Antioxidant determinations by the use of a stable free radical. Nature. 1958. 181: 1199-1200.

Brandes RP, Miller FJ, Beer S, et al. The vascular NADPH oxidase subunit p47phox is involved in redox-mediated gene expression. Free Radic Biol Med. 2002. 32: 1116-1122.

Carpino G, Morini S, Ginanni Corradini S, et al. Alpha-SMA expression in hepatic stellate cells and quantitative analysis of hepatic fibrosis in cirrhosis and in recurrent chronic hepatitis after liver transplantation. Dig Liver Dis. 2005. 37: 349-356.

da Silva BS, Paulino AMB, Taffarel M, et al. High sucrose diet attenuates oxidative stress, inflammation and liver injury in thioacetamide-induced liver cirrhosis. Life Sci. 2021. 267 118944. 
Friedman SL. Liver fibrosis - from bench to bedside. J Hepatol. 2003. 38 Suppl 1: S38-S53.

Gan D, Zhang W, Huang C, et al. Ursolic acid ameliorates CCl4induced liver fibrosis through the NOXs/ROS pathway. J Cell Physiol. 2018. 233: 6799-6813.

Hajovsky H, Hu G, Koen Y, et al. Metabolism and toxicity of thioacetamide and thioacetamide S-oxide in rat hepatocytes. Chem Res Toxicol. 2012. 25: 1955-1963.

Han JT, Oh SJ, Kim HY, Park YD, Baek NI. Hyperin, Antioxidant compounds isolated from the branch of Uncaria rhynchophylla Miq. J Appl Biol Chem. 2000. 43: 78-80.

Han M, Liu X, Liu S, et al. 2,3,7,8-Tetrachlorodibenzo-p-dioxin (TCDD) induces hepatic stellate cell (HSC) activation and liver fibrosis in C57BL6 mouse via activating Akt and NF- $\mathrm{KB}$ signaling pathways. Toxicol Lett. 2017. 273: 10-19.

Han NK, Jung MG, Jeong YJ, et al. Plasma fibrinogen-like 1 as a potential biomarker for radiation-induced liver injury. Cells. 2019. 8: 1042.

Heitzman ME, Neto CC, Winiarz E, Vaisberg AJ, Hammond GB. Ethnobotany, phytochemistry and pharmacology of Uncaria (Rubiaceae). Phytochemistry. 2005. 66: 5-29.

Islam T, Hasan MR, Roy A, et al. Screening of in-vitro antioxidant, brine shrimp lethality bioassay and antimicrobial activities of extracts of Bridelia retusa (L.) Spreng. fruit. Int J Pharm. 2015. 5: $1058-1067$.

Jia R, Cao LP, Du JL, et al. Effects of carbon tetrachloride on oxidative stress, inflammatory response and hepatocyte apoptosis in common carp (Cyprinus carpio). Aquat Toxicol. 2014. 152: 11-19.

Kim HS, Lee YS, Oh SK, et al. Effect of ramulus et uncus uncariae on glucose oxidase-induced toxicity in cultured cerebral neurons. J Physiol \& Pathol Korean Med. 2002. 16: 10161019.

Kim HY. Effects of water extracts of black tea on hepatic functional improvement and anti-fibrosis in rats. J East Asian Soc Diet Life. 2013. 23: 44-52.

Kim KH, Bae JH, Cha SW, Han SS, Park KH, Jeong TC. Role of metabolic activation by cytochrome $\mathrm{P} 450$ in thioacetamideinduced suppression of antibody response in male BALB/c mice. Toxicol Lett. 2000. 114: 223-235.

Kim ST, Kim JD, Lyu YS, Lee MY, Kang HW. Neuroprotective effect of some plant extracts in cultured CT105-induced PC12 cells. Biol Pharm Bull. 2006. 29: 2021-2024.

Koop AC, Thiele ND, Steins D, et al. Therapeutic targeting of myeloperoxidase attenuates NASH in mice. Hepatol Commun.
2020. 4: 1441-1458.

Lackner C, Tiniakos D. Fibrosis and alcohol-related liver disease. J Hepatol. 2019. 70: 209-304.

Lee UE, Friedman SL. Mechanisms of hepatic fibrogenesis. Best Pract Res Clin Gastroenterol. 2011. 25: 195-206.

Li J, Hu R, Xu S, et al. Xiaochaihutang attenuates liver fibrosis by activation of Nrf2 pathway in rats. Biomed Pharmacother. 2017. 96: 847-853.

Liang S, Kisseleva T, Brenner DA. The role of NADPH oxidases (NOXs) in liver fibrosis and the activation of myofibroblasts. Front Physiol. 2016. 7: 17.

Liu A, Shen Y, Du Y, et al. Esculin prevents lipopolysaccharide/DGalactosamine-induced acute liver injury in mice. Microb Pathog. 2018. 125: 418-422.

Loh YC, Ch'ng YS, Tan CS, Ahmad M, Asmawi MZ, Yam MF. Mechanisms of action of Uncaria rhynchophylla ethanolic extract for its vasodilatory effects. J Med Food. 2017. 20: 895911.

Marciniak S, Wnorowski A, Smolińska K, et al. Kynurenic acid protects against thioacetamide-induced liver injury in rats. Anal Cell Pathol (Amst). 2018: 2018. 1270483.

Nam Y, Ko SK, Sohn UD. Hepatoprotective effect of ultrasonicated ginseng berry extract on a rat mild bile duct ligation model. J Ginseng Res. 2019. 43: 606-617.

Ninan J, Feldman L. Ammonia levels and hepatic encephalopathy in patients with known chronic liver disease. J Hosp Med. 2017. 12: 659-661.

Park YM, Kim JA, Kim CH, Lim JH, Seo EW. Effects of cultured acer tegmentosum cell extract against hepatic injury induced by D-galactosamine In SD-rats. Korean J. Plant Res. 2015. 28: 551-560.

Park YM, Lee JE, Seo EW. Effect of semisulcospira libertina extract on hepatic injury induced by D-galactosamine. Korean J Environ Biol. 2018. 36: 498-506.

Piek A, Koonen DPY, Schouten EM, et al. Pharmacological myeloperoxidase (MPO) inhibition in an obese/hypertensive mouse model attenuates obesity and liver damage, but not cardiac remodeling. Sci Rep. 2019. 9: 18765.

Re R, Pellegrini N, Proteggente A, Pannala A, Yang M, Rice-Evans C. Antioxidant activity applying an improved ABTS radical cation decolorization assay. Free Radical Biol Med. 1999. 26: 1231-1237.

Robinson SM, Mann DA. Role of nuclear factor kappaB in liver health and disease. Clin Sci (Lond). 2010. 118: 691-705.

Singleton VL, Rossi JA. Colorimetry of total phenolics with 
phosphomolybdic-phosphotungstic acid reagents. Am J Enol Vitic. 1965. 16: 144-158.

Trefts E, Gannon M, Wasserman DH. The liver. Curr Biol. 2017. 27: R1147-R1151.

Wu CT, Deng JS, Huang WC, Shieh PC, Chung MI, Huang GJ. Salvianolic acid C against acetaminophen-induced acute liver injury by attenuating inflammation, oxidative stress, and apoptosis through inhibition of the Keap1/Nrf2/HO-1 Signaling. Oxid Med Cell Longev. 2019. 2019: 9056845.

Xu L, Yu Y, Sang R, Li J, Ge B, Zhang X. Protective effects of taraxasterol against ethanol-induced liver injury by regulating CYP2E1/Nrf2/HO-1 and NF-kB signaling pathways in mice.
Oxid Med Cell Longev. 2018. 2018: 8284107.

Yoon YC, Fang Z, Lee JE, et al. Selonsertib inhibits liver fibrosis via downregulation of ASK1/ MAPK Pathway of hepatic stellate cells. Biomol Ther (Seoul). 2020. 28: 527-536.

https://doi.org/10.15616/BSL.2021.27.3.142

Cite this article as: Choi JW, Shin MR, Lee JH, Roh SS. Hepatoprotective Effect of Uncaria rhynchophylla on Thioacetamide-Induced Liver Fibrosis Model. Biomedical Science Letters. 2021. 27: 142-153. 